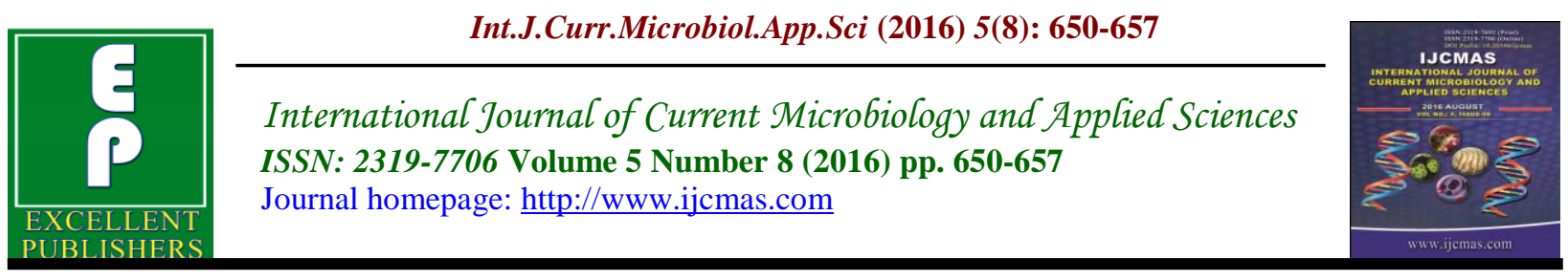

Original Research Article

http://dx.doi.org/10.20546/ijcmas.2016.508.073

\title{
Isolation, Enumeration and Antimicrobial Susceptibility of Predominant Microbes Associated with Currency Notes
}

\author{
V. Snehalatha, R. Malashree* and Preeti Soni \\ Department of Microbiology, M.S. Ramaiah College of Arts, Science and Commerce, \\ M.S.R.I.T post, Bangalore-54 India \\ *Corresponding author
}

\begin{abstract}
A B S T R A C T
Keywords

Currency notes, contamination, disinfectants, bacterial species, fungal species, occupational groups.

\section{Article Info}

Accepted:

25 July 2016

Available Online:

10 August 2016

Isolation, Enumeration and Antimicrobial susceptibility of predominant microbes associated with Currency notes was carried out to isolate the microflora present in each of the sample of currency notes and to analyze the load of microflora and their characterization. To create public awareness and personal hygiene after handling currency notes and to study the effectiveness of sanitizers and hand washes against potential pathogens. Maximum bacterial population noticed in different samples of currency notes upto $10^{9} \mathrm{CFU}$. Microbial population was more in case of currency notes. Most of the organisms were of Gram positive rods, cocci and also endospore formers and few Gram negative rods. Most of the fungal isolates from different sources include Penicillium sp., Cladosporium sp., Aspergillus sp., Trichoderma sp., Fusarium sp. and Yeast. The study also illustrates that there was persistence of resistant bacteria associated with currency notes against various disinfectants and natural antimicrobials. Among the tested organisms many were found to be susceptible to hand sanitizers than hand washes. There should be more emphasis given to the public regarding importance of personal hygiene.
\end{abstract}

\section{Introduction}

These days most commonly publically handled commodities include currency notes. Currency notes are commonly contaminated with potentially pathogenic microorganisms and this contamination played a significant role in the transmission of potentially harmful microorganisms for different diseases. The word "money" is originated from a temple of Hera, located on Capitoline, one of Rome's seven hills. Money is referred to as a currency that is usually in a form of notes and coins. Money is very important to human life as it is economically important and trade needs (Ormerod et al.,1997). Currency notes are necessary for goods and services worldwide. Banknotes are used from buying milk at local store to buying even drugs. The paper notes is handled by a large number of people increase the possibility of acting as environmental vehicle for the transmission of potential pathogenic microorganisms i.e. bacteria \& fungi (Abrams and Waterman, 1972; Venkatesh,1999).So, the infected currency is identified as potential public health hazard as pathogen spreads by 
circulating banknotes (Emikpe and Oyero, 2007). Studies of the contamination of money with microbial agents is lacking in most developing countries. Lack of information may contribute to the absence of public health policies regarding currency usage, handling and circulation. The contaminated currency notes go in circulation and contaminate the hands of others, transmitting microorganisms in the process (Adelowo, 1990). Other actions such as the wetting of hands or fingers with saliva or use of contaminated water to lubricate the hand in counting money could lead to transfer of parasite and bacteria from such medium to the notes. Paper currency offers a larger surface area as a breeding ground for pathogens. Microbes may persist on it for longer periods. The older the paper note the more accumulation of microbes occurs.

Microorganisms are found almost everywhere in our environment. Some microorganisms are useful but some are pathogenic. Paper Currency, can be contaminated by droplets during coughing, sneezing, or other materials and placement on dirty surface. The pathogenic or potentially pathogenic bacteria found on these currency notes may cause a wide variety of diseases from food poisoning, wound and skin infections, respiratory and gastrointestinal problems to life threatening diseases such as meningitis and septicemia. In addition, contamination of currency notes can also be traced to dust, soil, water, microflora of the body of handlers (hand, skin, etc.,) (Awe et al .,2010). Source of contamination could also be due to poor or negative money handling practices. Failure of food service workers to adequately sanitize hands or use food - handling tools between the handling of money and the serving of food could put food service at risk. Anything that gets on hands can get on money. There is a need for strict adherence to hygienic practices among money handlers. Storage of these contaminated notes in polythenes, cotton, leather bags in humid and dark conditions also favour the growth of bacteria on them. It is possible to detect the presence of particular bacteria on these notes by isolating the pathogenic bacteria on their respective growth media.

The present study was aimed at investigating the microbial contamination of currency notes of various occupational group including Bus conductor, Student, Street vendor, Sweeper, Lab assistant, Lecturer, Vegetable vendor, Pharmacist, Baker and Canteen patron, Rickshaw driver, Cashier in stationary shop, Construction and Butcher and their susceptibility to some commercially available hand sanitizers, hand washes and natural antimicrobials.

With a number of infectious intestinal diseases, a low dose of the infectious agent is capable of causing illness; therefore, failure of food service workers to adequately sanitizes hands or use food-handling tools between the handling of money and the serving of food could put food service patrons at risk (Michaels, 2002).

An individual living in unhygienic conditions and having unhygienic habits will contaminate the notes e.g., keeping currency notes in socks, shoes and pockets, under the carpet or rugs and squeezing them in the hand frequently introduces an array of microbes to the notes. Attitudes such as the wetting of hands or fingers with saliva or use of contaminated water to lubricate the hand in counting money and use of food contaminated fingers in handling currency notes may not only enhance the contamination of currency notes but may also increase the risk of infection from contaminated. Microorganisms on the skin can be transferred from cashiers, salespeople and the general public to the currency notes 
that they handle (Badvi et al., 2010). Recommendations are the washing of hand thoroughly by food handlers, whether at a restaurant or at home after handling currency and before handling food, regular disinfection of currency deposited in banks and post offices by ultraviolent light or formalin vapours (Singh et al., 2002), regular withdrawal of damaged notes by the federal authorities, and, most important, the improvement of personal hygiene.

The study was conducted to isolate the microflora present in each of the sample of currency notes and to analyze the load of microflora and their characterization. To create public awareness and personal hygiene after handling currency notes and to study the effectiveness of sanitizers and hand washes against potential pathogens.

\section{Materials and Methods}

\section{Sample collection}

Samples for currency notes were collected from person of Vegetable vendor, Butcher, Pharmacist, Baker, Cashier in stationary shop and from Rickshaw driver, Bus conductor, Street vendor, Construction labourer, Students.

Samples were collected in sterile polythene bags using gloves. Samples were taken carried to the lab within 24 hours and further processing.

Different samples of currency notes were analyzed according to the method given by Chesebrough, 2000.

\section{Isolation of microorganisms present on currency notes}

Bacteria and fungi were isolated from various samples of different occupational groups using Nutreint agar and potato dextrose agar. Bacterial count was determined using serial dilution technique (Chesebrough, 2000). The sample was serially diluted upto $10^{-9}$ dilution.

\section{Isolation of microbes using selective, differential and enriched media}

The samples from different occupational groups were also isolated by swab method using selective, differential and enriched media like EMB, Mac Conkey and Blood agar and further characterised.

Different colonies were further subjected to Grams staining. The organism which were concluded on the basis of Gram reaction and biochemical test were characterized as per standard method (Gram, 1884). Biochemical tests include Catalase (Loew, 1892) Oxidase (Gordon and McLeod, 1928) Indole (Macfaddin, 1980) Methyl Red (Voges, 1989).

\section{Antibiotic sensitivity test}

Different disinfectants in the form of Hand sanitizers, Hand washes and natural antimicrobials were used for the study as in table 2 .

\section{Antimicrobial activity}

The antimicrobial activity was studied by Agar well-Diffusion method given by

Perez et al., (1990) and diameter of the inhibition zones were recorded.

\section{Results and Discussion}

Investigations were conducted at the department of Microbiology MSRCASC, Bangalore to isolate different microflora present on Currency notes and to evaluate the effectiveness of disinfectants against the isolated microbes. 


\section{Sample collection}

Different samples of currency notes were collected as in table 1 .

\section{Isolation and characterization of bacterial and fungal isolates from different groups for currency notes}

Barolia et al., 2011, also noticed storage of currency notes in polythene, cotton or leather bags in humid and dark conditions also favours the growth of fungal and bacterial organisms on them. The colonies of bacteria had varying characteristics features with filamentous, undulated, entire and wrinkled margins and colours including yellow, cream, white and orange. Almost all the isolates had smooth texture with both raised and flat colonies with respect to elevation. The isolates were of Gram positive rods and cocci and few Gram negative rods and few were endospore formers. The different fungal and bacterial isolates, isolated from different sources, showed varied groups of microbes proliferating. The varied fungal isolates from different sources include Penicillium sp., Cladosporium sp., Aspergillus sp., Trichoderma sp., Fusarium sp. and Yeast.

Microbial assessment of various samples for presence of bacteria showed that all the samples from different occupational groups proving currency notes are good habitats for bacteria.

Similarly, with currency note samples of bus conductors, vegetable vendors, butcher recorded maximum bacterial population of $70 \times 10^{9} \mathrm{CFU}$ and least was noticed with student sample $\left(50 \times 10^{9} \quad \mathrm{CFU}\right)$. Currency notes being handled by large number of people increase the possibility of having more load of bacterial population on them.

Most predominant colonies were selected and analyzed further for biochemical tests and the result of the biochemical tests are given in table 4. Based on the Gram reaction, spore formation and biochemical tests the probable isolates could be Isolate 1- Staphylococcus sp. Isolate 2Streptococcus sp. Isolate 3 - Bacillus $s p$.

Dow Jones News, 1998; FSA, 2000, also reported contamination of currency notes with microorganisms among the food handlers.

The antibiotic sensitivity test against commercially available disinfectants revealed varying result for different organisms.

Table.1 Samples of currency notes for microbial analysis from different occupational groups

\begin{tabular}{|l|l|}
\hline $\begin{array}{l}\text { Serial } \\
\text { no. }\end{array}$ & $\begin{array}{l}\text { Different occupational } \\
\text { groups }\end{array}$ \\
\hline 1 & Bus conductor \\
\hline 2 & Vegetable vendor \\
\hline 3 & Baker \\
\hline 4 & Street vendor \\
\hline 5 & Pharmacist \\
\hline 6 & Rickshaw driver \\
\hline 7 & Construction labourer \\
\hline 8 & Student \\
\hline 9 & Cashier in stationary shop \\
\hline 10 & Butcher \\
\hline
\end{tabular}


Table.2 Different Disinfectants/ Hand sanitizers used for the study

\begin{tabular}{|l|l|}
\hline Sample no. & Disinfectants \\
\hline C & Control \\
\hline 1 & Dettol(HW) \\
\hline 2 & Lifebuoy(HW) \\
\hline 3 & Himedia(HW) \\
\hline 4 & Godrej protekt $(\mathrm{HW})$ \\
\hline 5 & Kleenol $(\mathrm{HW})$ \\
\hline 6 & Dettol(S) \\
\hline 7 & Lifebuoy(S) \\
\hline 8 & Himalaya(S) \\
\hline 9 & Cutarub(S) \\
\hline 10 & Sterillium(S) \\
\hline 11 & Sodium Chloride $(10 \%)$ \\
\hline 12 & Lemon extract \\
\hline 13 & Lemon extract+NaCl \\
\hline & $*$ HW- Hand wash \\
& $*$ S- Sanitizer
\end{tabular}

Table.3 Bacterial populations from different occupational samples for currency notes

\begin{tabular}{|l|l|l|}
\hline Serial no. & $\begin{array}{l}\text { Different } \\
\text { occupational } \\
\text { people group }\end{array}$ & $\begin{array}{l}\text { Bacterial } \\
\text { population } \times \mathbf{1 0}^{\mathbf{9}} \\
\text { CFU }\end{array}$ \\
\hline 1 & Bus conductor & 70 \\
\hline 2 & Vegetable vendor & 70 \\
\hline 3 & Baker & 60 \\
\hline 4 & Street vendor & 65 \\
\hline 5 & Pharmacist & 55 \\
\hline 6 & Student & 50 \\
\hline 7 & Cashier & 60 \\
\hline 8 & Rickshaw driver & 60 \\
\hline 9 & Butcher & 70 \\
\hline 10 & $\begin{array}{l}\text { Construction } \\
\text { labourer }\end{array}$ & 60 \\
\hline
\end{tabular}

Table.4 Biochemical tests of different microbes isolated from Currency notes

\begin{tabular}{|l|l|l|l|}
\hline $\begin{array}{l}\text { Biochemical } \\
\text { tests }\end{array}$ & Isolate 1 & Isolate 2 & Isolate 3 \\
\hline Catalase & + & - & - \\
\hline Oxidase & - & - & + \\
\hline Indole & - & - & - \\
\hline Methyl red & + & + & - \\
\hline $\begin{array}{l}\text { Voges- } \\
\text { proskauer }\end{array}$ & - & - & + \\
\hline
\end{tabular}


Table.5 Antibiotic sensitivity showing Resistant and susceptibility of samples

\begin{tabular}{|l|l|l|l|l|}
\hline \multirow{2}{*}{$\begin{array}{l}\text { Serial } \\
\text { no. }\end{array}$} & $\begin{array}{l}\text { Different } \\
\text { occupational } \\
\text { groups }\end{array}$ & $\begin{array}{l}\text { Staphylococcus } \\
\text { sp. }\end{array}$ & Klebsiella sp. & $\begin{array}{l}\text { Streptococcus } \\
\text { sp. }\end{array}$ \\
\hline C & Control & - & - & - \\
\hline 1 & Dettol & 1.15 & 1.33 & 2.25 \\
\hline 2 & Lifebuoy & 0.75 & - & - \\
\hline 3 & Himedia & 0.65 & - & - \\
\hline 4 & Godrej protekt & 1.0 & 0.88 & 2.5 \\
\hline 5 & Kleenol & 0.75 & 1.5 & - \\
\hline 6 & Dettol & - & - & - \\
\hline 7 & Lifebuoy & 0.6 & - & - \\
\hline 8 & Himalaya & - & - & - \\
\hline 9 & Cutarub & 1.38 & 1.58 & 2.5 \\
\hline 10 & Sterillium & - & 1.19 & 3.5 \\
\hline 11 & $\begin{array}{l}\text { Sodium } \\
\text { Chloride }(10 \%)\end{array}$ & - & - & - \\
\hline 12 & Lemon extract & - & - & - \\
\hline 13 & $\begin{array}{l}\text { Lemon } \\
\text { extract+NaCl }\end{array}$ & - & - & - \\
\hline
\end{tabular}

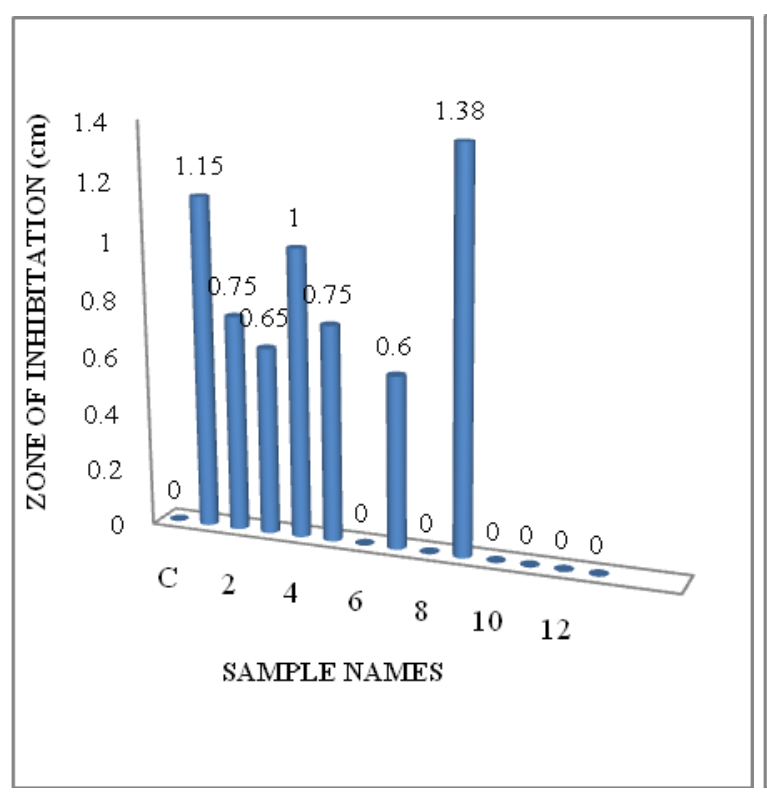

Fig.1 Antimicrobial activity of disinfectants against Staphylococcus sp.

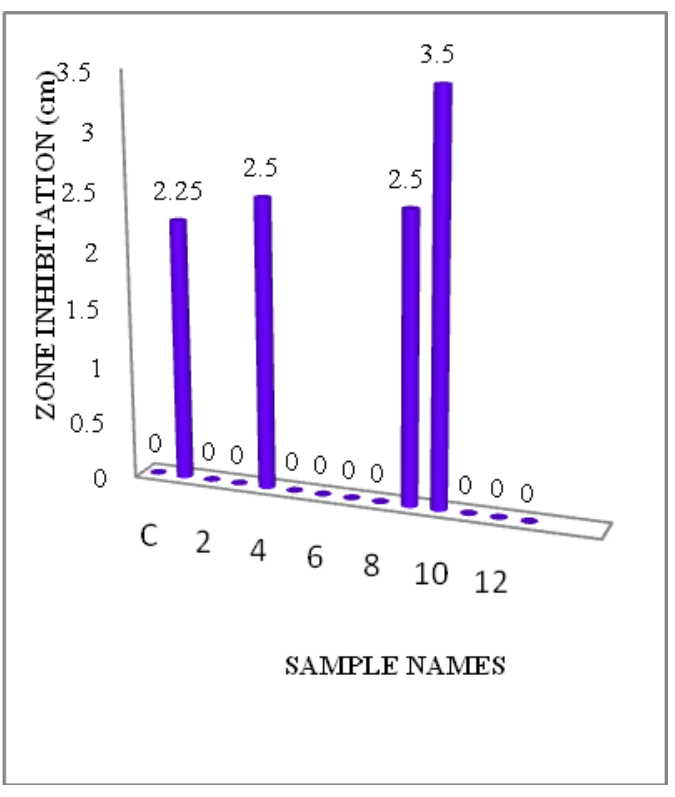

Fig.2 Antimicrobial activity of disinfectants against Streptococcus sp. 


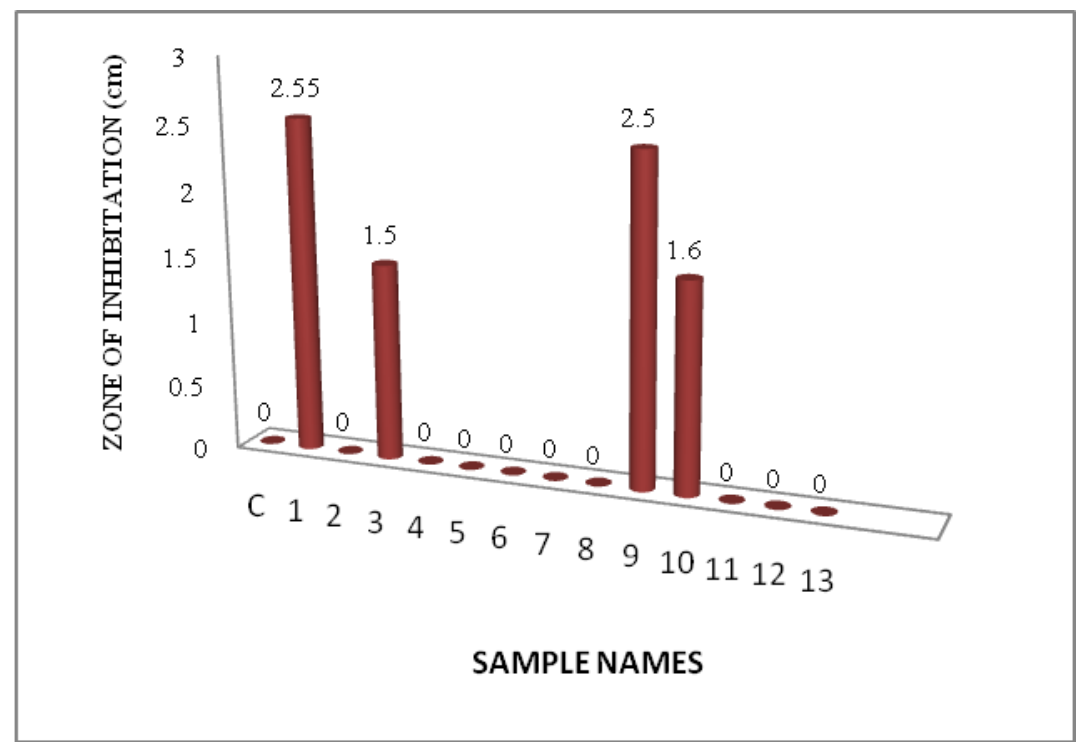

Fig.3 Antimicrobial activity of disinfectants against Bacillus sp.

Thus among different hand washes and sanitizers and natural antimicrobials, cutarub found to be most effective against all the tested organism followed by Dettol sanitizer and Sterillium. Whereas natural antimicrobials, both Sodium Chloride and lemon extract separately and in combination failed to show any effectiveness having no zone of clearance notice.

The research work was conducted to isolate the microflora present in currency notes from different occupational groups and to evaluate the effectiveness of disinfectants and natural antimicrobials against them. As currency notes are used by people on daily basis can give shelter to potential pathogens which serve as vectors of various infectious agents. Though the technological advancement has made a remarkable progress in various fields including communication in achieving improved economic status there are lot of concerns with it. The present study clearly demonstrated that the currency notes are commonly contaminated with pathogenic and non pathogenic microorganisms. The study also illustrates that there was persistence of resistant bacteria associated with currency notes against various disinfectants and natural antimicrobials. But most of the organisms were found to be susceptible to hand sanitizers, cutarub and dettol. There should be more emphasis given to the public regarding importance of personal hygiene as there is more prevalence of pathogenic microbes on currency notes. Further investigations are necessary to study effects of fumigants against the pathogenic microorganisms present in currency notes.

\section{Acknowledgement}

I am highly indebted to MSRCASC for providing valuable guidance for the accomplishment of my research work. The work was supported by Department of Microbiology, M.S. Ramaiah College of Arts, Science and Commerce.

\section{References}

Abrams, B.L and Waterman, N.G. 1972. Dirty Money.Journal of American Medical Association, 219: 1202 1203. 
Adelowo, O.A. 1990. Intestinal Helminthiasis in a Post -Secondary Institution in Ilorin, Kwara state, Nigeria. The Nigerian J. Parasitol., 9(11): 91-94.

Awe, S., Eniola, K.I.T., Ojo, F.T. and Sani, A. 2010. Bacteriological quality of some Nigerian currencies in circulation. African J. Microbiol. Res., 4: 2231-2234.

Badvi, J. A., Hafiz, S., Baloch, L., Soomro., Z.A. 2013. Various outlets are the potential source of bacterial infections through the Pakistan currency notes. Med. Channel, 19: 87-92.

Barolia, S.K., Verma, S. and Verma, B.K., 2011. Coliform contamination on different paper currency in Ajmer, Rajastan, India. Universal J. Environ. Res. Technol., 1: 552-556.

Chesebrough, M. 2000. Medical laboratory manual for tropical countries Volume 11. Second edition, University Press, Cambridge, Great Britain, 377pp.

Dow Jones News. 1998. Dirty and Contaminated Money. A New Short book of Medical Parasitic fufection. ELBS Publishers. pp: 576-582.

Gram, H.C. 1884. "Uber die isolierte Farabung der Schizomyceten in Schnitt-Und Trockenpraparaten”.
Fortschritte der Medizin (in German) 2: $185-189$.

LEOW, O. 1892. Catalase: a new enzyme of general occurance, with special reference to the tobacco plant by Washington Government printing office 68: 368-394.

MacFaddin, Jean, F. 1980. "Biochemical Test for Identification of medical bacteria." Williams and Wilkins. pp 173-183.

Michealis, M.T., Marlinko, J.M., Parker, J. 2002. Brook Biology of Microorganisms. $9^{\text {th }}$ Edition, Prentice Mall, Engle woods Cliffs, New Jersy.pp:957.974.

Oyero, O.G., Emikpe, B.O. 2007. Preliminary investigation on the microbial contamination of Nigerian currency. Int. J. Trop. Med., 2: 29-32.

Perez, C., Paul, M., Bazerque, P. 1990. Antibiotic assay by agar-Well diffusion method. Acta. Biol. Med. Exp., 15: 113-115.

Singh, A.Y., Thakur, B.A., Kalpana, R.E. and Gog. 2002. Isolation .of various Contaminants on Currency. Medical Microbiology, third Edition, Mosby Publishers. pp: 186.

Voges, O. and Proskauer, B. 1898. Zeit. Hgy., 28: 20-32.

\section{How to cite this article:}

Snehalatha, V., R. Malashree and Preeti Soni. 2016. Isolation, Enumeration and Antimicrobial Susceptibility of Predominant Microbes Associated with Currency Notes. Int.J.Curr.Microbiol.App.Sci. 5(8): 650-657. doi: http://dx.doi.org/10.20546/ijcmas.2016.508.073 